Zohreh, Wan Zailan \& Mohammad Ali, , "The Conception of Modesty and Modest Dress," Afkār Vol. 18 Issue 2 (2016): 229-270

\title{
THE CONCEPTIONS OF MODESTY AND MODEST DRESS IN THE SCRIPTURES OF ABRAHAMIC RELIGIONS
}

\author{
KONSEP KESOPANAN DAN PEMAKAIAN SEDERHANA \\ WANITA DALAM TEKS AGAMA-AGAMA IBRAHIM
}

\section{Zohreh. Sadatmoosavi*, Wan Zailan Kamaruddin Wan Ali* $^{* *}$ Mohammad Ali Shokouhi ${ }^{* * *}$}

${ }^{* * *}$ Academy of Islamic Studies. University of Malaya.

50603. Kuala Lumpur. Malaysia.

Email: *zsm1@ siswa.um.edu.my

\begin{abstract}
Khulasah
Lebih dua dekad yang lalu, isu norma kesopanan dan pemakaian wanita yang sederhana telah dibincangkan secara meluas dalam wacana akademik dan media. Pada asasnya, kesopanan bukan milik mana-mana budaya tertentu tetapi hari ini, ia telah menjadi subjek penelitian yang sengit dalam konteks Islam. Walau bagaimanapun, semua kitab agama samawi baik alQuran, Perjanjian Lama dan Perjanjian Baru telah memberikan penekanan kepada persoalan maruah dengan melihatnya sebagai kuasa moral dan sosial untuk kedua-dua jantina lelaki dan wanita, dan mencadangkan pemakaian sederhana untuk wanita biarpun menggunakan konsep dan terma yang berbeza-beza. Di samping itu, dari segi sejarah dan tradisi dalam kalangan para penganut agama tersebut, mereka mengaitkan tingkah laku sederhana dengan perintah agama. Kajian ini akan meneroka persamaan penting konsep kesopanan dan pemakaian sederhana wanita dalam agama Yahudi, Kristian dan Islam dengan melihat kepada aspek norma kesopanan wanita, pemakaian sederhana dan kepentingannya.
\end{abstract}

Kata kunci: konsep kesopanan, pakaian sederhana, wanita, agama Ibrahim. 


\begin{abstract}
Over the past two decades, the issue of modesty norms and women's wearing modest dress were widely discussed in academic and media discourse. Basically, modesty does not belong to any specific culture but today it has become the subject of intense scrutiny in the Islamic context. However, all scriptures of Abrahamic religions; the Qur'an, Old and New Testaments have emphasized on the observing modesty as a moral and social virtue for both men and women and recommended modest dress for women despite of using different conceptions and terms. In addition, historically and traditionally, among the followers of these religions observing modest behaviors has been regarded as religious commandment. This research will explore the conceptions of modesty and modest dress of women in Judaism, Christianity and Islam to clear the essential similarities of Abrahamic faiths regarding to modesty norms and using modest dress for women and their significance.
\end{abstract}

Keywords: Conception, modesty, modest dress, women, Abrahamic religions.

\title{
Introduction
}

Nowadays, women's bodily practices not only function as a mechanism that reflects women's position in culture, but also suggest "a powerful resource for negotiating, redefining, and conceptualizing that position". ${ }^{1}$ Over the past two decades, the issue of modesty behaviors and women's wearing modest dress has widely been discussed in academic and media discourse. Beside several academic researches on the modest dress in relation to Muslim

1 Reischer, Erica, and Kathryn S. Koo, "The Body Beautiful: Symbolism and Agency in the Social World," Annual Review of Anthropology (2004), 315. 
women $^{2}$, there are also some investigations about the Jewish and Christian women's head covering. ${ }^{3}$

In fact, in all Abrahamic religions, keeping modesty as a moral and social virtue has been emphasized as human nature and the observance of chastity and preserving privacy against strangers has a special significance. The scope of this research is the teachings of Abrahamic religions. The Abrahamic (or Semitic) religions in this study refer to the three faiths: Judaism, Christianity and Islam that assert the prophet Abraham

2 Ahmed, Leila, Women and Gender in Islam: Historical Roots of a Modern Debate (Yale: Yale University Press, 1992); Read, Jen'nan Ghazal and John P. Bartkowski, "To Veil or not to Veil? A Case Study of Identity Negotiation among Muslim Women in Austin, Texas," Gender \& Society 14(3) (2000): 395-417. Daly, M. Catherine, "The 'Paarda' Expression of Hejaab among Afghan Women in a non-Muslim Community", In Religion, Dress and Body, ed. Arthur L.B. (New York: Berg, 1999): 147-161; El Guindi, Fadwa, Veil: Modesty, Privacy, and resistance (Oxford: Berg, 1999); Hoodfar, Homa, "The Veil in their Minds and on our Heads: Veiling Practices and Muslim Women," The Politics of Culture in the Shadow of Capital (1997): 248-279; Mohanty, Chandra Talpade, "Under Western Eyes: Feminist Scholarship and Colonial Discourses," Feminist Review 30 (1988): 61-88; Lorasdağ1, Berrin Koyuncu, "The Headscarf and 'Resistance Identity-Building': A Case Study on Headscarf-Wearing in Amsterdam," Women's Studies International Forum32(6) (2009): 453-462; Castelli, Elizabeth A., and Rosamond C. Rodman, Women, Gender, Religion a Reader (New York: Palgrave, 2001), 420-446; Marshall, Gül Aldikaçti, "Ideology, Progress, and Dialogue: A Comparison of Feminist and Islamist Women's Approaches to the Issues of Head Covering and Work in Turkey," Gender \& Society 19(1) (2005): 104-120.

3 Zalcberg, Sima. "Grace is Deceitful and Beauty is Vain: How Hassidic Women Cope with the Requirement of Shaving One's Head and Wearing a Black Kerchief," Gender Issues 24(3) (2007): 13-34; Schachter, Elli P., "Identity Configurations: A New Perspective on Identity Formation in Contemporary Society," Journal of Personality 72(1) (2004): 167-200; Seigelshifer, Valeria and Tova Hartman, "From Tichels to Hair Bands: Modern Orthodox Women and the Practice of Head Covering," Women's Studies International Forum, vol. 34(5) (2011): 349-359. 


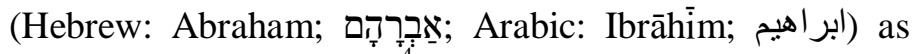
their common forefather. ${ }^{4}$ The Oxford Dictionary defines Abrahamic religions as denoting any or all of the religions that revere Abraham as the Biblical patriarch. ${ }^{5}$

This study refers to the concept of modesty as sexual modesty. In fact, particularly today, the concept of modesty is so elusive and its definitions tend to be in some cases controversial. ${ }^{6}$ Several contemporary authors have attempted to explain modesty in measurable traits ${ }^{7}$ for the purpose of conducting new empirical studies $^{8}$ or of integrating existing findings 9 . However, some definitions could be faulted for being overly meticulous and prioritizing rigor. Therefore, there is a need to negotiate between rigor and coverage in order to develop a good theoretical definition of a phenomenon. ${ }^{10}$

Therefore, in a number of qualitative studies, the actual word of modesty has been used and considered as a description of behaviour. It is been noted in numerous modern qualitative studies that modesty is considered

${ }^{4}$ Hunter, Preston, "Major Religions of the World Ranked by Number of Adherents," accesed August 23, 2011, http://www. adherents. com/Religions_By_Adherents. html>(2007).

${ }^{5}$ Oxford Dictionaries, Oxford University Press, accessed Oct 15 2010, http://oxforddictionaries. com/definition/english/VAR.)

6 Andrews, Caryn Scheinberg, "Defining and Exploring Modesty in Jewish American Women," Journal of Religion and Health 50(4) (2011): 818-834.

${ }^{7}$ Ibid.

${ }^{8}$ Cialdini, Robert B., et.al., "When Social Role Salience Leads to Social Role Rejection: Modest Self-Presentation among Women and Men in Two Cultures," Personality and Social Psychology Bulletin 24(5) (1998): 473-481.

9 P. Gregg et.al., "The Importance of Being Modest," in The Self: Frontiers in Social Psychology, eds. C. Sedikides \& S. Spencer (New York: Psychology Press, 2007), 163-184.

10 P. Gregg et.al., "Everyday Conceptions of Modesty: A Prototype Analysis," Personality and Social Psychology Bulletin (2008). 
practicing "safe sex",11 and a barrier to seeking attention for breast symptoms ${ }^{12}$, breastfeeding ${ }^{13}$ in many cultures. ${ }^{14}$

In two recent preconceptions, modesty in women takes precedence over that in men. ${ }^{15}$ In fact, a person who behaves modestly abstains from extroverted conduct that is supposed to speak of him or her. This expansive view would also include sexual modesty. ${ }^{16}$ So, modesty has been defined as 'a mark of sexual purity and respectable womanhood', while 'false modesty', a term derived in the 1930s, carried connotations of silliness and

${ }^{11}$ Flores-Ortiz, Yvette G, "The Role of Cultural and Gender Values in Alcohol Use Patterns among Chicana/Latina High School and fUniversity Students: Implications For AIDS Prevention," International Journal of the Addictions 29(9) (1994): 1149-1171.

${ }^{12}$ Facione, Noreen C., "Breast Cancer Screening in Relation to Access to Health Services," Oncology Nursing Forum26(4) (1999): 689696.

${ }^{13}$ Raisler, Jeanne, "Against the Odds: Breastfeeding Experiences of Low Income Mothers," Journal of Midwifery \& Women's Health 45(3) (2000): 253-263.

${ }^{14}$ Scheinberg, "Defining and Exploring Modesty in Jewish American Women," 818-834.

${ }^{15}$ See: Heatherington, Laurie, et.al., "Toward An Understanding Of Social Consequences of "Feminine Immodesty" About Personal Achievements," Sex Roles 20(7-8) (1989): 371-380; Rudman, Laurie A., "Self-Promotion as a Risk Factor for Women: The Costs and Benefits of Counterstereotypical Impression Management," Journal of Personality and Social Psychology 74(3) (1998): 629; Wosinska, Wilhelmina et.al., "Self-Presentational Responses to Success in the Organization: The Costs and Benefits of Modesty," Basic and Applied Social Psychology 18(2) (1996): 229-242.

${ }^{16}$ Ahituv, Yosef, "Modesty and Sexuality in Halakhic Literature, Jewish Women: A Comprehensive Historical Encyclopedia", Jewish Women's Archive, accessed Oct 15 2013, http://jwa.org/encyclopedia/article/modesty-and-sexuality-inhalakhic-literature. 2009. 
embarrassment. ${ }^{17}$ Nevertheless, a few recent works have yielded various accounts of modesty.

For example, in the Julia Driver account, modesty is a form of ignorance entailing a lack of self-knowledge, and it is odd to say that this ignorance constitutes a virtue. ${ }^{18}$ However, Shalit writes that modesty is not a social construct, but a natural response. Shalit also went on to say that modesty is not prudery, but a way to preserve a sense of the erotic in our lives. ${ }^{19}$ In fact, modesty is a mode of dress and deportment intended not to encourage sexual attraction in others but, actual standards vary widely.

Nonetheless, modesty virtue is not unique to specific cultures. Modesty is a highly-valued attribute in all cultures, even in contemporary Western society, ${ }^{20}$ but the standards of modesty somehow vary by culture or generation. Most discussions on modesty involve clothing. Men and women are subject to different standards of modesty in dress. Besides, historians and anthropologists show that hair has diverse socio-religious and symbolic value in many civilizations. ${ }^{21}$

${ }^{17}$ Reagan, Leslie J., "Engendering the Dread Disease: Women, Men and Cancer," American Journal of Public Health 87(11) (1997): 1779-1787.

18 Allhoff, Fritz, "What is modesty?" International Journal of Applied Philosophy 23(2) (2009): 165-187.

19 Shalit, Wendy, A Return to Modesty: Discovering the Lost Virtue (New York: Simon and Schuster, 2000), 125.

${ }^{20}$ Eagly, Alice H. and Barbara A. Acksen, "The Effect of Expecting to be Evaluated on Change Toward Favorable and Unfavorable Information about Oneself," Sociometry (1971): 411-422; Jones, Edward Ellsworth and Camille B. Wortman, Ingratiation: An Attributional Approach (New York: General Learning Press, 1973). Leary, Mark R. The Curse of the Self: Self-Awareness, Egotism, and the Quality of Human Life (Oxford: Oxford University Press, 2004).

21 Hallpike, Christopher R. "Hair." The Encyclopedia of Religion 6 (New York: MacMillan, 1987): 154-157. 
Therefore, the term 'modesty' can be used in several senses. This research however, deals with the particular character traits in relation to sexual modesty, and will discuss about modest dress that point towards an observance of certain mores in most of cultures. This usage certainly stands in some relation to the character trait of modesty since being modest might well engender modest dress. ${ }^{22}$

\section{The Conceptions of Modesty and Modest Dress in Judaism}

Hebrew Bible or Tanakh ${ }^{23}$ and Talmud ${ }^{24}$ are considered as the most important sources of this religion. The Jewish notion and standards of modesty in dress and conduct that is particularly relating to women is known as Tzniut, according to Orthodox Judaism as derived from various sources in the Halakha (Jewish law) ${ }^{25}$.

${ }^{22}$ Fritz, "What is modesty?", 165-187.

${ }^{23}$ Tanakh is the collection of writings as the holy books of Jewish people. This term is an acronym that derived from the names of the three divisions of the Hebrew scripture: Torah (Instruction, or Law, also called the Pentateuch), Nevi'im (Prophets) and Ketuvim (Writtings). J. Coert Rylaarsdam, Encyclopedia Britannica, vol 12, (Chicago: Encyclopaedia Britannica, 2009), 33. Encyclopedia Britannica, accessed Oct 8, 2014, http://global.britannica.com/EBchecked/topic/1785796/Tanakh.

24 The Talmud is a collection of study teachings based upon the Hebrew Bible and oral commentaries of Jewish learning. Most of the Rabbis cited in the Talmud lived from 20 B.C.to 450 A.D. In fact, name of two works which have been preserved to posterity as the product of the Palestinian and Babylonian schools during the Amoraic period, which extended from the third to the fifth century C.E. One of these compilations is entitled "Talmud Yerushalmi" (Jerusalem Talmud) and the other "Talmud Babli" (Babylonian Talmud). Used alone, the word "Talmud" generally denotes "Talmud Babli." Online Jewish Encyclopedia, accessed Oct 8, 2015, http://www.jewishencyclopedia.com/articles/10729-Talmud.

25 Henkin, Yehuda-Herzl, "Contemporary Tseni'ut," Tradition: A Journal of Orthodox Jewish Thought 37(3) (2003): 1-48. 


\section{a. Tzniut (Modesty)}

Usually, in Judaic culture, modesty is called tseni'ut, zeni'ut or tzniut (Hebrew: צניעות). ${ }^{26}$ This term is used in two meanings: humility and also the character of being modesty; mostly it has been used with regard to the rules of dress for women. In fact, tzniut is important not only in aspects of clothing but also extends to behavior. Today, in academic debates tzniut as the Jewish standards of modesty in dress and conduct is often the focus. ${ }^{27}$

This section examines the Tanakh and Talmudic teachings regarding this concept of tzniut so as to clarify the discussion on its meaning. The concept of tzniut has a great influence within Orthodox Judaism and sometimes within Conservative Judaism. The conceptual definition of tzniut, with reference to the Tanakh, contains two expressions related to its root, but neither of them is explicitly connected with sexual modesty. The verb tzana (to be humble) exists in Prov 11:2 and 'walk humbly' in Micah 6:8. The prophet Micah, as an example of the expansive view of modesty states:

He has told you, O man, what is good, and what the Lord requires of you: only to do justice and to love goodness, and be tzanua (modestly) in walking with your God ( והצנע (לכת עם א-להיך. ${ }^{28}$

Micah considers modesty as one of God's commands: "be tzanua in walking with your God". Willing also referred to the same evidence:

${ }^{26}$ The Sephardi pronunciation is "tzeniut" and Ashkenazi pronunciation is "tznius". Online Jewish Encyclopedia, accessed Oct 8, 2013, http://www.encyclo.co.uk/define/Tzniut.

27

Henkin, Yehuda-Herzl, "Contemporary Tseni'ut," Tradition: A Journal of Orthodox Jewish Thought 37(3) (2003): 1-48.

28 Micah 6:8, The Torah Web Foundation, accessed Oct 8, 2015, http://www.torahweb.org/torah/2010/parsha/rwil_bamidbar.html. 
Hashem $^{29}$ (God) had spoken to Moshe: Tznius (modesty) is beautiful, as it says in (Micha $6: 8)$; to walk humbly in (before) your G-d. ${ }^{30}$

Also, in the Babylonian Talmud ${ }^{31}$, there is an injunction at Micah 6:8 to walk humbly with your God as referring to modesty and discretion in dress and behavior. $^{32}$ In fact, humility is an utmost ideal within Judaism. ${ }^{33}$ Furthermore, Moses (PBUH) is considered as "exceedingly humble, more than any man in the world". The Talmud also states that humility is one of the characteristic traits of the Jewish people, ${ }^{34}$ as evident in the fact that Moses (PBUH) is considered as "exceedingly humble, more than any man in the world". ${ }^{35}$

${ }^{29}$ Hashem is the Hebrew word which many pious Jews use instead of the yod-hey-vav-hey (יהוה- YHVH) name, in casual conversations, and literally means "The Name". Hillel, ben David (Comments submitted to Rabbi Dr. Greg Killian Greg Killian), accessed Oct 8, 2014, http://www.betemunah.org/.

${ }^{30}$ G-d: A way of avoiding writing a name of G-d in some Jewish literature, to avoid the risk of the sin of erasing or defacing the Name. Willig, Mordechai, Modesty: A Timeless Principle, The Torah Web Foundation, accessed Oct 8, 2015, http://www.torahweb.org/torah/2010/parsha/rwil_bamidbar.html,

${ }^{31}$ The Babylonian Talmud is a collection of study teachings based upon the Hebrew Bible and oral commentaries of Jewish learning. Most of the Rabbis cited in the Talmud lived from 20 B.C.to 450 A.D." In fact, name of two works which have been preserved to posterity as the product of the Palestinian and Babylonian schools during the Amoraic period, which extended from the third to the fifth century C.E. One of these compilations is entitled "Talmud Yerushalmi" (Jerusalem Talmud) and the other "Talmud Babli" (Babylonian Talmud). Used alone, the word "Talmud" generally denotes "Talmud Babli," (Online Jewish Encyclopedia (1906) Accessed Oct 20, 2015, http://www.jewishencyclopedia.com/articles/10729-Talmud)

${ }^{32}$ Talmud, Tractate Sukkah 49b.

${ }^{33}$ Eidelberg, Paul, Judaic Man: Toward a Reconstruction of Western Civilization (The Caslon Company, New Jersey, 1996), 193.

${ }^{34}$ Talmud, Tractate Yevamot 79a.

${ }^{35}$ Tanakh, Numbers 12:3. 
As mentioned earlier, the concept of tzniut has a dual meaning in the moral manners literature (especially in the Kabbalistic ${ }^{36}$ thought) with a few differences in the nature of modesty in men and women. ${ }^{37}$ Wisdom is also linked with tzniut. In the Proverbs of Solomon it is stated: “...but wisdom is with the modesty (zenu'im"; צנועים ואת "חכמה "38 There is only one sentence on wisdom and tzniut, where the next paragraph is about humbleness. Another appearance of tzniut is assumed to be in relation to humbleness. Nevertheless, the rabbinic literature has made expansive use of this term with sexual connotations, although it still has not led to its meaning. So, tzniut, in its broad sense is considered as a mode of ethical conduct related to humility. Therefore, a person who behaves modestly abstains from exhibitive manners when speaking of themselves. This extensive view also includes sexual modesty. ${ }^{39}$

Falk elaborates on tznius as a "woman's ultimate distinction", as it relates to her purity, humility and righteousness. ${ }^{40} \mathrm{He}$ explains the two meanings of tznius and writes that this word literally means 'hidden' and is

${ }^{36}$ The Kabbalah (also Cabala, Kabala, Kaballah, Qaballah, etc.) is a mystical Jewish tradition that teaches that the elect of God shall know both Him and the universe and will be raised above common knowledge to a spiritual level where they will understand the secrets of Holy Writ and creation through symbolic interpretation. Kabbalists affirm that the elect shall discover in the ancient texts whatever they choose, and they have the right to assert that the things they discover had been in the sacred scriptures from the beginning. "Kabbalah," Gale Encyclopedia of the Unusual and Unexplained, accessed Oct 4, 2015, http://www.encyclopedia.com/doc/1G2-3406300163.html.

37 Ahituv, "Modesty and Sexuality in Halakhic Literature".

38 Tanakh, Proverb11:2.

${ }^{39}$ Ahituv, "Modesty and Sexuality in Halakhic Literature".

${ }^{40}$ Falk, E., Sefer 'Oz Ve-hadar Levushah: Modesty, an Adornment for Life: Halachos and Attitudes Concerning Tznius of Dress \& Conduct (New York: Feldheim Publishers, 1998), 228-240. 
used to describe two attributes that are seemingly totally different. For refinement of dress, conduct and also for the trait of unpretentiousness and humility, the opposite of which is arrogance and pride. ${ }^{\mathbf{1 1}}$

The same occurs in the English language where the word 'modesty' is used to describe people possessing both these traits, which appear to be unconnected and are two very different attributes. ${ }^{42}$ Therefore, tzniut includes several instructions in modest conduct such as the prohibition of negiah $^{43}$ (physical contact or touch between men and women), kol Isha ${ }^{44}$ (the voice of a woman) and other immodest sexual behavior that is referred to as kalut rosh (literally, frivolity).

\section{b. Derekh Erez (Proper Social Conduct)}

Another word linked to the meaning of the concept of modesty is the term "derekh erez" that also has a dual meaning in the rabbinic literature. In addition to demonstrating polite and proper general social conduct, it also expresses direction and recommendations about sexual behavior. Even though, the term tzniut prevailed when referring to sexual connotation, over time this meaning began to be taken over by the term derekh erez. ${ }^{45}$

\footnotetext{
${ }^{41}$ Ibid.

42 Sepinwall, Sharyn Weinstein, "Women of Valour: Literacy as the Creation of Personal Meaning in the Lives of a Select Group of Hassidic Women in Quebec" (Thesis, Faculty of Education McGilI University, Canada, 2002), 43.

${ }^{43}$ Negiah: literally "touch," is the concept in Halakha that forbids or restricts physical contact with a member of the opposite sex (except for one's spouse, children, siblings, grandchildren, parents, and grandparents). Even HaEzer 21:7 and Beis Shmuel 14; Fuchs, Rav Yitzchak Yaacov, "Halichos Bas Yisrael," Targum Pr, Oak Park, 1985, Mich 107.

${ }^{44}$ Accoding to Talmud: Berakhot 24a, Kiddushin 70b and Sotah 48a of Shmuel's statement: "Kol b'isha Ervah," the voice of a woman is Ervah, as it is written, "Sweet is your voice, comely your appearance." Tanakh, Song of Songs 2:14.

45 Ahituv, "Modesty and Sexuality in Halakhic Literature".
} 
Also, the rabbis use the word kalut rosh when referring to immodest sexual behavior. This term has been used by the Talmud in its account of the separation of men from women at some Jewish celebrations. The Oral Law ${ }^{46}$ tradition is the source of all the legal restrictions relating to modesty and the obstructions restrictions against arayot (literally nakedness) is the forbidden incestuous sexual relationships; also applied in a more general sense to all forbidden behavior of sexual nature). ${ }^{47}$ The word of arayot is used in the Torah as below:

None of you shall come near anyone of his own flesh to uncover nakedness. ${ }^{48}$

Another basic verse in which modesty has been recommended is:

When you go out as a troop against your enemies, be on your guard against anything untoward. $^{49}$

Several explanations use this verse as a general Biblical base for modest and reserved behaviour as well as a caution against sexual provocations. This general recommendation includes different prohibitions, such as gazing at a woman or even her clothing, and looking at

46 The Torah has two parts: The "Torah Shebichtav" (Written Law). which is composed of the twenty-four books of the Tanakh, and the "Torah Sheba'al Peh" (Oral Law). Originally the Oral Law was not transcribed. Instead it was transmitted from father to son and from teacher to disciple (thus the name "Oral" Law). According to Jewish tradition, the Oral Torah was passed down orally in an unbroken chain from generation to generation until its contents were finally committed to writing following the destruction of the Second Temple in $70 \mathrm{CE}$, when Jewish civilization was faced with an existential threat. See Schwartz, Howard. Tree of souls: The mythology of Judaism (Oxford University Press, 2004) iv.

${ }^{47}$ Ibid.

${ }^{48}$ Tanakh, Leviticus, 18:6

${ }^{49}$ Tanakh, Deuteronomy 23:10 
coupling animals (BT Avodah Zarah 20a-b). ${ }^{50}$ Today, modern Orthodox women cover their hair in a variety of ways; with scarves (tichels ${ }^{51}$ in yiddish ${ }^{52}$ : tikhl), kerchiefs $^{53}$ (bandanas), wigs (shaitels), hats, berets and baseball caps. ${ }^{54}$

Generally, in traditional Jewish sources an agreement indication towards wearing modest dress can be clearly seen for women in public places. As a matter of fact, a main specification of observance in Jewish women lives is hair modest conduct. ${ }^{55}$ Today, hair covering as a symbol has become a visible marker of differentiation between religious and secular women and additionally, has also considered as a distinction factor among various affiliations or subdivisions in the religious communities.

In fact, the concept of tzeniut covers more than just head covering (covering all main parts of the body) in many of the halakhic rules and the use of head covering is one of the prescribed religious attire for Jewish men and women by different bounds based on gender basis. Generally, modest behavior is a must for both the male and the female in the sexual realm. ${ }^{56}$ The conception of modesty entitled of tzeniut has several meanings as a

${ }^{50}$ Ahituv, "Modesty and Sexuality in Halakhic Literature".

51 Tichel: also called a mitpachat (Hebrew מִ mițpahat). a headscarf worn by married Jewish women in compliance with the code of modesty known as tzeniut. (Accessed Oct 2, 2013, http://www.yourdictionary.com/tichel)

52 Yiddish: A language based on German that is written in Hebrew characters and that was originally spoken by Jews of central and eastern Europe

53 Kerchief: (from the French couvre-chef, "cover the head") also known as a bandana is a triangular or square piece of cloth tied around the head or around the neck. (www.encyclo.co.uk/define/Kerchief)

${ }^{54}$ Seigelshifer, et.al., "From Tichels to Hair Bands," 349-359.

${ }^{55}$ Fuchs, Ilan. Hair Covering for Single Women: A New Reading of Mizrahi Halakhic Rulings. Nashim: A Journal of Jewish Women's Studies \& Gender Issues23 (2012): 35-59.

${ }^{56}$ Ahituv, "Modesty and Sexuality in Halakhic Literature". 
symbol. ${ }^{57}$ One of the key rationalizations made for head covering justification is that it protects the woman's sexual modesty in the society. ${ }^{58}$

\section{The Conception of Modesty and Modest Dress in Christianity}

Christian scholars in explaining modesty at the first stage refer to Hebrew biblical resources (especially in interpretations on Micah $6: 8^{59}$ ) that modesty is humility in person and dress. They have demonstrated via 1 Peter, 1 Timothy and 1 Corinthians in the Gospel to show that modesty and proper behaviour are not compatible with showy and too much attention in appearance. ${ }^{60}$ Even though, the Bible states:

But the Lord said to Samuel: “...for man looks at the outward appearance, but the Lord looks at the heart." 61

57 Ternikar, Farha, "Hijab and the Abrahamic Traditions: A Comparative Analysis of the Muslim Veil," Sociology Compass 3(5) (2009): 754-763.

58 Weiss, Susan, "Under Cover: Demystification of Women's Head Covering in Jewish Law," Nashim: A Journal of Jewish Women's Studies \& Gender Issues 17(1) (2009): 89-115.

${ }^{59}$ Tanakh, Micah 6: 8: "What does the Lord require of thee? But to do justly and to love mercy and to walk humbly [modestly] with thy God."

60 See: Hurley, James B., Man and Woman in Biblical Perspective (Oregon: Wipf and Stock Publishers, 2002); Martin, Troy W., "Paul's Argument from Nature for the Veil in 1 Corinthians 11: 1315: A Testicle Instead of a Head Covering," Journal of Biblical Literature 123(1) (2004): 75-84; De Courtais, Georgine, Women's Headdress and Hairstyles in England from AD 600 to the Present Day (London: BT Batsford Limited, 1986), 130; Murphy-O'Connor, Jerome, "Sex and Logic in 1 Corinthians 11: 2-16," Catholic Biblical Quarterly Washington, DC 42(4) (1980): 482-500; Hurley, James B., "Did Paul Require Veils or the Silence of Women? A Consideration of 1 Cor. 11: 2-16 and 1 Cor. 14: 33b-36," Westminster Theological Journal 35(2) (1973): 190-220.

${ }^{61}$ Tanakh, 1 Samuel 16: 7. 
Jesus emphasises on proper action even when looking:

You have heard that it was said to those of old, 'You shall not commit adultery.' But I say to you that whoever looks at a woman to lust for her has already committed adultery with her in his heart. ${ }^{62}$

Hence, modesty is defined in different actions and is not equal to clothing, but how and what we wear can be immodest or modest. To understand its exact meaning, we must refer directly to the language of the Gospels.

\section{a. Kosmios (Modesty)}

Although the word 'modesty' has not been mentioned in Genesis, the principle of modesty is established through literal events. For example, God covered Adam and Eve and established a moral attitude that is reinforced through several verses in the Hebrew Bible and Gospel. The term 'modesty' is used three times in the epistles of Peter and Paul and is considered to be divinely arranged. The apostle Peter teaches Christian ladies:

Do not let your adornment be merely outward — arranging the hair, wearing gold, or putting on fine apparel — rather let it be the hidden person of the heart, with the incorruptible beauty of a gentle and quiet spirit, which is very precious in the sight of God. For in this manner, in former times, the holy women who trusted in God also adorned themselves, being submissive to their own husbands. ${ }^{63}$

He persists that wives obey their husbands. Thus, Christian ladies are instructed to adorn themselves with a meek and quiet spirit. Peter explains this attitude by

\footnotetext{
${ }^{62}$ Matthew 5: 27-28.

${ }^{63} 1$ Peter 3: 3-7.
} 
labelling godly women. ${ }^{64}$ Paul also addressed this description:

I desire that in every place the men should pray, lifting holy hands without anger or quarrelling; also that women should adorn themselves modestly and sensibly in seemly apparel, not with braided hair or gold or pearls or costly attire but by good deeds, as befits women who profess religion. ${ }^{65}$

To understand the exact meaning of the related words, we need to examine them in their Greek roots and the different versions of the Gospel. Crank writes in this regard that 'modest apparel' ${ }^{66}$ or 'proper clothing' ${ }^{67}$ is translated from the Greek words, kosmios katastole. Kosmios means orderly and well arranged, modest and descent. Katastole refers to a garment, derived from the verb meaning "to send or let down, to lower" (kata =down, stello =to send), thus referring to a long flowing dress. ${ }^{68}$ Both of these passages (1 Timothy and 1 Peter) argue that immodesty partly results from inappropriate and luxury dress, hair style and adornments. Therefore, both of Peter and Paul want Christian ladies to dress appropriately.

${ }^{64}$ Crank, David, "Clothing \& Modesty," Magazine Unless the Lord 3(2) (2002).

651 Timothy 2: 8-10 RSV.

661 Timothy 2:9 in King James Bible (KJV) states: "In like manner also, that women adorn themselves in modest apparel, with shamefacedness and sobriety; not with broided hair, or gold, or pearls, or costly array."

67 The same verses in the New American Standard Version (NAS): "Likewise, I want women to adorn themselves with proper clothing, modestly and discreetly, not with braided hair and gold or pearls or costly garments, but rather by means of good works, as is proper for women making a claim to godliness."

${ }^{68}$ Crank, "Clothing \& Modesty". 


\section{b. Katakephale (Head Covering)}

The most important verse in this relation is in Paul's first epistle to Corinthians. In this verse he emphasises katakephale (head covering) and women refraining from unveiling the head:

But every woman who prays or prophesies with her head uncovered dishonours her head, for that is one and the same as if her head were shaved. ...Judge among yourselves. Is it proper for a woman to pray to God with her head uncovered ${ }^{69}$

Paul's notorious dispute in 1 Corinthians about women's head covering in public worship is often criticised for its complexity and logical confusion. ${ }^{70}$ There are several traditional and modern commentaries about this account. Some contemporary interpreters have tried to develop new meanings from this doctrine. To do so, they must begin with precisely understanding the terms used in Paul's. Literally, the term 'covered' means 'lower the head' which is translated from the Greek root of katakephale. Katakaluptos means 'completely covered' and akatakaluptos means 'not completely covered'. ${ }^{71}$ In this phrase: "With her head unveiled", 'unveiled' is a translation of akatakaluptos. ${ }^{72}$

Accordingly, as Troy writes in his article, Paul trains Christian women to cover their head because it is

${ }^{69} 1$ Corinthians 11: 6,13.

70 Troy, "Paul's Argument from Nature for the Veil in 1 Corinthians $11, " 75-84$.

71 Nyamaah, Emmanuel and Matilda Nsiah, "Alice Christianity and Culture in Ghana: A Study of the Church of Pentecost's Decree on Head Covering and 1 Corinthians 11:2-16," Proceedings, 1st Annual International Interdisciplinary Conference, AIIC 2013 (Azores, Portugal, 24-26 April 2013), 155

${ }^{72}$ Vine, William Edwy, An Expository Dictionary of New Testament Words: With Their Precise Meanings for English Readers (Nashville: Thomas Nelson Inc, 1985), 174. 
considered a part of women's genitalia. This means that Paul wanted women to cover their head in public worship and to dress modestly when around men. ${ }^{73}$ Even though Troy proclaims there is no modern scholar who agrees with the fundamental notions Paul promoted regarding the veil, everybody agrees with preventing showing genitalia in public worship. ${ }^{74}$ Massey states that the meaning of katakephale asserts that when head commonly used with an object indicates a kind of garment or cloth coming down from the head.",75

\section{c. Veil and Chapel Veil}

The definition of the word veil according to Webster is, "a length of cloth worn by women as a covering for the head and shoulders and, especially in Eastern countries, for the face". Blanket, mask, and robe were synonyms of the veil used in the $13^{\text {th }}$ century. ${ }^{76}$ Coffman in his Commentary on 1 and 2 Corinthians writes that this term has the meaning of 'veil' which when used in this passage five times refers to a large loose mantle which women wrapped around their heads and faces, leaving only the eyes visible, and sometimes only one eye. ${ }^{77}$ Brown writes that Paul required women to cover their hair with a material head covering. ${ }^{78}$

73 Troy, "Paul's Argument from Nature for the Veil in 1 Corinthians $11, " 75-84$.

${ }^{74}$ Ibid.

${ }^{75}$ T. Massey, "Preston the Meaning of $\kappa \alpha \tau \alpha \kappa \alpha \lambda \hat{v} \pi \tau \omega$ and $\kappa \alpha \tau \grave{\alpha} \kappa \varepsilon \varphi \alpha \lambda \tilde{\eta} \varsigma$ है $\chi \omega v$ in 1 Corinthians 11.2-16," New Testament Studies, 53(4) (2007): 522.

76 Tabatabai, Fakhrossadat, "The Veil: Symbol and State Identity, Iran and France" (International Relations Master's Program, University of Massachusetts Boston, John W. McCormack Graduate School of Policy and Global Studies, 2011), 16.

77 Coffman, James Burton (1999), Coffman Commentreis on the Old and New Testament, accessed July 20, 2015, http://www.studylight.org/commentaries/bcc/

${ }^{78}$ Brown, A. Philip, "A Survey of the History of the Interpretation of 1 Corinthians 11:2-16 II,” Aldersgate Forum, accessed July 22, 2015, 
In summary, Paul's expression could be that Christian women should have long hair and wear head covering at least in churches. Thus, the practice of prayer veiling as a devotional covering, chapel veil or mantilla has long existed as a tradition throughout Christian history.

\section{d. Mantilla (Mantle)}

One of the concepts that should be examined in relation to modest dress is mantle. This word is used in the Bible in different meanings. The Old Testament mentioned mantle as a garment of some prophets such as Elijah and Elisha. According to the International Standard Bible Encyclopaedia, this term has accrued five times about Elijah's mantle (1 King 19: 18, 19; 2 King 2:8, 13, 14). Furthermore, it is found as a plural once (Isaiah 3:22), where it refers to an upper wide tunic with sleeves (Kethoneth) ${ }^{79}$ In King 2:13-14, the mantle is considered the passing from Elijah the prophet to Elisha (his successor) symbolises the passing of prophetic authority. Smith's Bible Dictionary categorised the meaning of the mantle as:

i. The garment with which Jael covered Sisera (Judges 4:18)

ii. Authorized version rendered 'coat', 'cloak' and 'robe' (1 Samuel 15:27; 28: 14; Ezra 9: 3 Ezra 9: 5)

iii. Apparently some article of a ladies' dress (Isaiah $3: 22$ )

http://www.disciplingnewconverts.org/web_documents/OtherArticle s/2011-10-25, 2011.

79 Orr, James, ed., The International Standard Bible Encyclopaedia 4 (Chicago: Howard-Severance Company, 1915). Entry for 'mantle'; D.D. General Editor, accessed Oct 3, 2015, http://www.studylight.org/encyclopedias/isb/view.cgi?n=5735\&sear ch=span. 
iv. The sole garment of the prophet Elijah (1 Kings 19:13 1 Kings 19:19, 2 Kings 2:8 2 Kings 2:13 2 Kings 2:14) $)^{80}$

Although there are variations of the meaning of mantle in the Bible, the leading notion is clothing like a cloak or other article of covering. In biblical times, a mantle was usually a large, loose garment made of animal skin, probably sheepskin. According to the Bible, a mantle was known as a prophet's official garment or a sign of a prophet calling from God (1 King 19:13). ${ }^{81}$ Christians believe God has regarded a mantle as a call upon every believer in Jesus Christ (1 Peter 4:10-11), as priests believe that their mantles are their God-given spiritual gifts.

The covered head is God's chosen emblem to remind all of His children some fundamental facts which $\mathrm{He}$ has intended for their happiness and His glory. ${ }^{82}$ Traditionally, Christians call the women's veil as mantle. In this context, head coverings requirement of the priesthood are unambiguous: every priest was expected to wear a headdress of fine linen and the high priest was to wear his head-covering continually. ${ }^{83}$

\section{e. Habit}

It is a long, loose garment worn by a member of a religious order (nuns in long brown habits, black veils,

${ }^{80}$ Smith, William et.al., Smith's Bible Dictionary, "entry for 'mantle,"' accessed July $6 / 2015$, http://www.classic.studylight.org/dic/sbd/view.cgi?number=T2830>.

81 The prophet Samuel wore a mantle (1 Samuel 15:27). The prophet Elijah "threw his cloak around [Elisha]" as a symbol of Elijah's ministry being passed on to Elisha. So, the prophet's mantle was an indication of his authority and responsibility as God's chosen spokesman (2 Kings 2:8).

82 Shank, Tom, An in-depth study of 1 Corinthians 11:1-16 (North America Torch Publications, 1992).

${ }^{83}$ Exodus 28: 4, 37-38: 39.28; Leviticus, 16.4: 21.10 1xx: Ezekiel, 44.18; Zechariah, 3.5 . 
and sandals). ${ }^{84}$ As Kuhns writes, the nun's habit is one of the most familiar religious symbols in the world. As she writes, "Habit refers to the ensemble of clothing and accessories that make up this religious dress. From this garment, a woman is recognised as a person who determined to serve her life to God." $" 85$

Sullivan in Consuming Fashion writes that the nun's habit that looks like a satanic uniform has reacted to moral and social transition throughout history. ${ }^{86}$ Eichner mentions that habit is a sign of "obedience, poverty, and chastity-forever". ${ }^{87}$ Nuns' habits are in a variety of shape and colour depending on the church or sect. It usually consists of a tunic, belt, capuse (hood), cappa (great cloak) and scapular (a kind of apron). ${ }^{88}$

Generally, there was no change in scholars' thought against women veiling in church until the $20^{\text {th }}$ century, even though chapel veils or mantillas are still mostly used by catholic women especially in formal audience with the Pope. According to Christian attitudes, celibacy is considered sacred, thus in the interest in eliminating the possibility of stimulation and attraction, Christianity invites women to avoid unnecessary decoration. In addition to underlining the issue of modesty, in Christianity the head covering is considered as a divine

${ }^{84}$ Dictionary Oxford English, Oxford University Press, accessed July 6, 2015, http://www.oxforddictionaries.com/definition/english/habit

${ }^{85}$ Kuhns, Elizabeth, The Habit: A History of the Clothing of Catholic Nuns (Bournemouth: Image, 2007), 8.

${ }^{86}$ Sullivan, Rebecca, "Breaking Habits: Gender, Class and the Sacred in the Dress of Women Religious," Consuming Fashion: Adorning the Transnational Body (1998): 109-128.

87 Eichner, Maura, "A Nun Changes Her Habit," Catholic Digest, accessed July 22, 2015, http://www.sturdyroots.org/PDFs/CF/CF_EichnerHabitpdf.pdf, 1963.

${ }^{88}$ C. Sheehy, Mary, The Dominican Habit, accessed June 21, 2014, www.dominicanidaho.org/formation/.../dominican.habit.history.pdf, 1989. 
order and a symbol of submission to God's government, especially during times of public worship. ${ }^{89}$

Throughout Christian history, dressing modestly has been as a symbol of purity and modesty for believing and faithful women. In this context, one of the symbols of monasticism formed from the third century of Christian history is having modest dress particularly for women. Many images on the walls of the catacombs ${ }^{90}$ depict Christian women veiled while the men are bareheaded. The church fathers such as Clement of Alexandria (AD 150-220) and Tertullian (AD 160-215) in their commentaries of Jesus, Peter and Paul have stressed on the issue of modesty and modest dress. Protestant reformers and many church leaders have emphasized on modest clothing in addition to the large body of Christian teachings in the earlier centuries towards dress. ${ }^{91}$

Nonetheless, today, this subject has been failed to be taught by many churches except in certain religious groups such as most Amish, Mennonite communities and Pentecostals that are still observe modest norms. However, many Christian women used to cover their hair in churches until the 1950s. Even the Catholics declared that after Vatican II $^{92}$ the head covering is not mandatory

89 Nee, Watchman, An In-depth Study of 1 Corinthians 11:1-16 (Richmond, Torch Publications, North America) accessed July 3, 2015 ,

http://truthinheart.com/EarlyOberlinCD/CD/Doctrine/BeVeiled.htm, 1975.

90 Catacombs: a series of underground passages and rooms where bodies were buried in the past. The Cambridge Advanced Learners Dictionary \& Thesaurus (Cambridge: Cambridge University Press) accessed June 5, 2015, http://dictionary.cambridge.org/dictionary/british/catacomb

${ }^{91}$ Crank, "Clothing \& Modesty".

${ }^{92}$ Vatican II, The popular name for the Second Vatican Council, an assembly of all the bishops of the Roman Catholic Church held from 1962 to 1965 . The bishops ordered a large-scale liberalization and modernization of practices in their church. See: The American 
anymore. ${ }^{93}$ Fashion is what majority of Christians seem to follow today that typically lead them to immodesty while the minority of them only try to dress modestly. ${ }^{94}$ There are still several theologians who believe in the importance of the veil and modesty, despite the debates about this issue among contemporary Christian academics.

\section{The Conceptions of Modesty and Modest Dress in Islam}

Islam like other Abrahamic religions emphasizes on observing modesty as a moral and social virtue. One of the most important Islam's virtues is modesty. The Prophet (PBUH) states, means:

Every religion (Deen) has an innate character; the character of Islam is modesty. ${ }^{95}$

Modesty and belief are fully associated together if one is lifted the other follows suit. ${ }^{96}$

Islamic teachings consider modesty in all behaviours and practices including in dress, which includes the wearing of the veil. Nevertheless, being modest in dress was not introduced by Islam. Scholars such as El Guindi and Mernissi claim that historically, wearing modest dress can be traced to pre-Islamic times in Mesotopian and

Heritage ${ }^{\circledR}$ New Dictionary of Cultural Literacy, Vatican II, Third Edition, accessed June, 6, 2015, http://dictionary.reference.com/browse/vatican ii)

${ }^{93}$ T. Lewis, John, The Posture in Prayer and Covered and Uncovered Heads in Worship (Birmingham, AL, 1947). 14.

${ }^{94}$ Crank, "Clothing \& Modesty."

95 Ibn Mājah al-Qazwīni, Muḥammad bin Yazìd, al-Sunan Ibn Mājah (Beirut: Dār al-Fikr, 1415/1995), No. 4182 إنَّ لِكَلِّ دِينِ خُلُقًا ، وَإِنَّ خُلُقُقَ " الإسنْلامِ الْحَيَاءُ

Also see: Mālik Ibn Anas, al-Muwațta', vol. 47 (Beirut: Dār al-Fikr, 1398 /1978), 9:

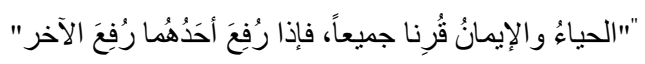


Mediterranean areas. ${ }^{97}$ Ahmed believes that wearing the veil was not institutionalized before Islam. $^{98}$ In some cases, the stricter rules of modesty are seen in ancient Iran, India and other non-Arab cultures. ${ }^{99}$ A style of women covering from head to toe was known in ancient Mesopotamia around $3000 \mathrm{BC}$. In addition, the Old Testament demonstrates that the women of ancient Babylonia and Judea used various kinds of veil. ${ }^{100}$

In any case, it was Islam that established the rules of modesty in Arabia ${ }^{101}$ despite some Arabian tribes observing modest dress. ${ }^{102}$ The verses about modesty rules

${ }^{97}$ Mernissi, Fatima, Women and Islam: An Historical and Theological Inquiry (Missouri: South Asia Books, 1991).

${ }^{98}$ Leila, Women and Gender in Islam.

99 The oldest statute with regard to the veiling of women known today is the Middle Assyrian Law (BC 1300). A man who saw one who was forbidden to do so wearing a veil and who failed to report the breach to the authorities would also be punished. Driver, Godfrey Rolles et.al., eds., The Assyrian Laws (Amsterdam: Scientia Verlag, 1975), 406-409.

${ }^{100}$ There are many references to the use of veils or face-veils in the Old Testament. For example see: Genesis 24:64-65 and Isaiah 47:2. "And make not a dazzling display, like that of the former times of ignorance."

${ }^{101} \mathrm{Al}$-Qur'an demonstrates this matter when says to the Prophet wives to cover themselves properly: "And make not a dazzling display, like that of the former times of ignorance." Al-Ahzāb (33): 33

${ }^{102}$ Abū al-Faraj al-Ișfahāni (897-967) in his book The Book of Songs, has quoted the story of "the War of Fojjar" which occurred near Mecca at the end of the sixth century as bellow: "On the day of the 'Ukaz market, a beautiful girl of the Amir tribe was sitting in the market place, wearing a burqu', a face-veil. Young men from Quraish and the Kinana tribe saw her and crowded around her to ask her to take off her burqu'. After she refused, one of the youths played a trick on her, secretly attaching her garment to a stick. Not knowing what he had done, she stood up. Consequently her dir (outer garment) slipped down, baring her back. They jeered at her, saying, "Since you refused to show your face, now you have been reduced to showing us your back." "Oh, people of Amir!" she cried. Thus the fight between the tribes of Amir and Kinana, lasting for four years, began." Abū al-Faraj al-Ișfahānī, Kitāb al-Aghānī, 
are revealed over 10 years of Islamic government after the migration to Medina and each of these rules was based on the event or phenomenon that God has been expressed its command. All madhhab (main legal schools of Islam) mandate that women are recommended to be modestly dressed in public. ${ }^{103}$

Wearing modest dress allows women to enjoy more freedom in the public spheres, including secure access to work and education. Also some Islamic feminists have argued that the veil is actually a liberating tool that protects and empowers women. ${ }^{104}$ As a matter of fact, the basic reasons for wearing modest dress are clearly stated in the Qur'anic verses, which call for women to cover their adornments so as to be modest and to protect themselves. Throughout Islamic history, the wearing of the Islamic dress often called Hijab has manifested in different ways in various countries taking multiple forms, including the jilbāb, khimār, chadur, parda, burqa, tudung, and niqāb. The Qur'an has demonstrated the importance of modesty in numerous verses, from which we note the following:

\section{a. Hayā' (Modesty)}

God not only wants women to conceal their beauty, but also walk modestly and decently. The Qur'an appreciated the manner in which the daughter of Prophet Shua $y b$ walked:

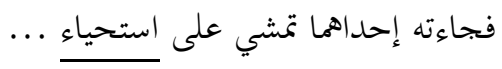

ed. Ị̣sān 'Abbās et al. vol. 19 (Cairo, Beirut: Dār Șadr, 2003), 7374.

103 Siddiqui, Mona, 'Veil,' in Encyclopedia of the Quran, ed. J. McAuliffe (Leiden, Netherlands: Brill Academic Publishers, Leaman, O, 2004). 412-416.

104 Bullock, Katherine, Rethinking Muslim Women and the Veil: Challenging Historical \& Modern Stereotypes (Virginia: IIIT, 2002) 
Afterwards one of the (damsels) came (back) to him walking bashfully. ${ }^{105}$

Literally, the Arabic word hayā' is derived from hayāt which refers to the meaning of life. Hay $\bar{a}^{\prime}$ implies a bad and uneasy feeling accompanied by embarrassment that causes one to fear being exposed for some unworthy or indecent conduct. Some mix the meanings of two terms of haya ' (modesty) and shyness. Shyness is a natural consequence of fear from being worthless before others and is a negative character. However, hay $\bar{a}$ ' is a natural feeling of embarrassment from doing something out of purity and neatness to keep the individual from immorality. There are interesting hadiths about hay $\bar{a}$ ' from the prophet of Islam:

"Faith (İmān) has over 70 branches, and modesty is a branch of faith." 106

Also, it is narrated that he stated: "Haya " brings forth nothing but goodness.",107

\section{b. Chastity (' $I f f a h$ )}

Rāghib al-Iṣfahāni (d. 402H.) writes about the meaning of iffah that:

Chastity is obtaining the state of the soul that refrains from the predominance of lust. ${ }^{108}$

In the Qur'an, modesty ('iffah) has been used four times from the root of ('affa) of which two ${ }^{109}$ are generally in the meaning of piousness, self-control and selfprotection. The other two verses ${ }^{110}$ refer to a sense of

\footnotetext{
105 Al- Qașaș 28:25

106 Al-`Asqalānī, Ibn Hajar, Fatḥ al-Bārī Sharh Ṣaḥịh al-Bukhārī, vol 1 (Riyadh: Dār Al-Salam, 2000).

107 Ibid.

108 Rāghib al-Ișfahāni, al-Mufradāt fī Gharīb al-Qur'ān, vol. 2

(Damascus: Dār al-Qalam, 1992), 440.

109 Al-Baqarah 2:273, al-Nisā' 4:6.

وليستعفف الذين لايجدون نكاحا حتي يغنيهج الله من فضله 110
} 
sexual restraint by refraining from sexual sins when single.

\section{c. Jilbāb (modest dress)}

One of the manifestation of the chastity ('iffah) and modesty (hay $\bar{a}$ ') is having appropriate and modest dress. As such, in the Qur'anic verses along with recommendations for observing modesty, there is the requirement to dress modestly such that a woman should cover her body in association with none-mahram men (whom she is not related to according to the Divine Law) and that she does not flaunt and display herself. Throughout history, a variety of Islamic modest dress in different societies has been used but there are only three words in relation to the issue of women covering in the Qur'an. ${ }^{111}$ One of the word that the Qur'an uses in this relation is jalabib which is the plural form of the word jilbāb. The Qur'anic verse in this regard is:

O Prophet! Say to your wives and daughters and the believing women that they draw their jilbāb (outer garments) close to them; so it is more proper that they may be known and not hurt. ${ }^{112}$

"But let them who find not [the means for] marriage abstain [from sexual relations] until Allah enriches them from His bounty..." AlNūr 24:33:

و القواعد من النسأ اللا تي لا يرجون نكاحأ فليس عليهن جناحُ ان يضعن ثيابهن

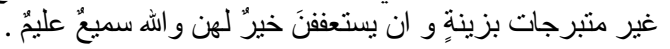

"Such elderly women as are past the prospect of marriage,- there is no blame on them if they lay aside their (outer) garments, provided they make not a wanton display of their beauty: but it is best for them to be modest ..." Al-Nūr 24:60.

111 Ameli, Saied Reza,Hijab, Meaning, Identity, Otherization and Politics: British Muslim Women, vol. 4 (Islamic Human Rights Commission, 2006), 69.

112 Al-Aḥzāb 33:59. 
Rāghib al-Iṣfahāni writes that it implies both dress and scarf. ${ }^{113}$ Ibn al-Manzūr (1233 -1311) stated:

Jilbāb is actually the outer sheet or coverlet which a woman wraps around on top of her garments to cover herself from head to toe. It hides her body completely. ${ }^{114}$

For more explanation, in defining the word, Ibn Al-Hazm (994-1064) writes:

In the Arabic language; the language of the Prophet (PBUH), jalābib was outer sheet which covers the entire body. A piece of cloth which is too small to cover the entire body could not be called jilbāb. ${ }^{115}$

Therefore, in this verse, Muslim women, along with the prophet's wives and daughters, are commanded to wear a fully covering garment when they are in public. ${ }^{116}$

\section{d. Khimār (Head Covering)}

The third word in this regard in the Qur'an is Khimār:

Say to the believing women that they cast down their glance and guard their private parts and reveal not their adornment except such as is outward and let them cast their veils (khumur) over their bosoms. ${ }^{117}$

The vast majority of commentators and jurists approve that this verse orders believing woman to draw her existing head covering over the jayb (which is the collar

${ }^{113}$ Rāghib al-Ișfahāni, al-Mufradāt fī Gharīb al- Qur'ān, 66.

${ }^{114}$ Ibn Manẓūr, Jamāl al-Dīn Muhammad, Lisān al-`Arab, vol. 1 (Iran, Qom: Nashr Adab Hawzih,1405 AH), 273.

${ }^{115}$ Ibn Hazm, Abū Muhammad 'Alī ibn Aḥmad ibn Sa'̄̄, al-Muhallā, tahqiq Shākir, Aḥmad Muḥammad, vol. 3 (Lebanon: Dār al-Kutub al-'Ilmiyyah, 2012), 217.

116 Motahhari, Murtadha, The Islamic Modest Dress, trans: Laleh Bakhtiar (Chicago. IL: Kazi Publications, 1992), 96.

${ }^{117}$ Al-Nūr 24:31. 
line or bosom). In this Qur'anic verse, the term khimār (in plural form) is clearly used as head covering. ${ }^{118}$ In addition to these mentioned terms, the encyclopedia of Islam has classified over 100 terms as pieces of female clothing such as burqa, abayah, jilbab, jallābah, nigāb and izar. ${ }^{119}$ Generally, in Islamic scholarship, hijāb is still taken to mean 'modest dress' and conduct. ${ }^{120}$ In this study, the term 'modest dress' with the exception of quotes.

\section{e. Hijāab}

In recent times, the term hijāb (حجاب) is symbolically used for Islamic modest dress and sometimes refers to modest behavior. Scholars define hijāb in a variety of ways and associate it with diverse meanings that range from covering of the head to modest behavior. ${ }^{121} H i j \bar{a} b$ has various meanings in the Qur'an. Literally, it means a cover, curtain or screen. According to Lane's ArabicEnglish Lexicon, its meaning is:

A thing that prevents, hinders, debars, or precludes; a thing that veils, conceals, hides, covers, or protects, because it prevents seeing, or beholding. ${ }^{122}$

The Qur'an has mostly used the word hijāb in a metaphysical sense, as the illusory feature of creation. ${ }^{123}$

\footnotetext{
${ }^{118}$ Saied, Hijab, Meaning, Identity, Otherization and Politics, 69.

119 Anwar, Ghazala, Veiling in Encyclopedia of Islam and the Muslim World, vol. 2 (New York: Macmillan, 2004), 721-722.

${ }^{120}$ Ssenyonjo, Manisuli, "The Islamic Veil and Freedom of Religion, the Rights to Education and Work: A Survey of Recent International and National Cases," Chinese Journal of International Law 6(3) (2007): 653-710.

121 Ruby, Tabassum F, "Listening to the Voices of Hijab," Women's Studies International Forum 29(1) (2006): 54-66.

${ }^{122}$ Lane, Edward William, and Stanley Lane-Poole, An Arabic-English Lexicon: Derived from the Best and the Most Copious Eastern Sources, vol. 2 (London: Williams and Norgate, 1865).

${ }^{123}$ Ibrahim, B. Syed, Women in Islam: Hijab Aalim, vol. 7 (Louisville: Islamic Research Foundation (IRF), 1999).
} 
In total, the term hijāb is used for seven times in the Qur'an ${ }^{124}$ (generally in the meaning of hinder and curtain) that one of them ${ }^{125}$ is appeared in the meaning of curtain between men and women and is related to wives of the prophet of Islam as the Mothers of believers ${ }^{126}(\mathrm{ra})$ and says:

And when you ask (his wives) for anything you want, ask them from behind a screen (hijāb); that makes for greater purity for your hearts and for theirs. ${ }^{127}$

Accordingly, the true meaning of hijāb is not veil but curtain. $^{128}$ It is not used as a technical term in jurisprudence for women's dress code in Islam. As a matter of fact, the usual term in Islamic jurisprudence is sitr or sātir (السنر، الساتر, cover). Jurists, in the section of ritual prayer and marriage, the term sitr would be used and not hijäb when they discuss clothing. ${ }^{129}$ Mutahhari in his book The Islamic Modest Dress attempts to question this popular usage of this term:

But there is a question as to why, in the recent era, did the current expression of the religious jurisprudents, that is sitr (a technical word that is used for covering body and includes the other words) not become prevalent instead of hijāb? The reason is unknown to me. Perhaps

\footnotetext{
${ }^{124}$ These verses are: al-A 'rāf, Maryam, al-Isra', al-Fușṣilāt, al-Shūrā, al-Aḥāb.

${ }^{125}$ Al- Ahzāb 33:53.

${ }^{126}$ Al-Ahizāb 33:6.

127 Al- Ạ̣zāb 33:53.

${ }^{128}$ Khan, Sumbul Ansar, "Notion of Veil in Islam: A Sign of Placate or Disconcert among the Women of Karachi, Pakistan," Asian Journal of Social Sciences \& Humanities 3 (2014): 2.

${ }^{129}$ Motahhari, The Islamic Modest Dress, 5.
} 
they mistook the Islamic hijab for the hijāb which is traditional in other countries. ${ }^{130}$

In answering this question, El- Guindis writes:

When the veil became the centre of the feminist/nationalist discourse in Egypt during the British colonial occupation, hijāb was the term used by feminists and nationalists and secularists. The phrase used for the removal of urban women's face/head cover was raf' (lifting) al-hijāb (not al-Habarah the term used for cloak/veil among upper-class Egyptian women at the turn of the century). ${ }^{131}$

Hence, it seems that there was a deliberate usage of this term in the feminists' dialogues, because they have not used an already existing term of habarah in public. This term refers to a variety of different head coverings and loose dress styles nowadays. Some with cultural connections are Pakistani shalwar khamis, Afghani burqa, Iranian chador, and Malaysian tudung. Anyway, when such dress is worn, it is considered that they have worn a hijāb.

Recent decades have had a substantial emphasis on the term hija $\bar{b}$ which is mostly understood as only a headscarf. ${ }^{132}$ Unlike common Western presumptions, the headscarf is not interchangeable with the term hija $\bar{a} b^{133}$ or in better term 'modest dress'. Today, the term hijāb is mostly used in West and specifically in media to express the concept of headdress or scarf-like and sometimes overall clothing of Muslim women. ${ }^{134}$

${ }^{130}$ Ibid., 6.

${ }^{131}$ Al-Ali, Nadje, "Veil: Modesty, Privacy and Resistance," Journal of the Royal Anthropological Institute 6(3) (2000): 153.

${ }^{132}$ Farha, "Hijab and the Abrahamic Traditions," 754-763.

${ }^{133}$ Saied, Hijab, Meaning, Identity, Otherization and Politics, 71.

${ }^{134}$ Ibid., 69. 


\section{Conclusion}

All the scriptures of Abrahamic religions; the Qur'an, Old and New Testaments, have emphasised on the observing modesty as a moral and social virtue for both men and women and recommended on modest dress for women despite of using different conceptions and terms.In Judaic teachings, modesty in sexual behaviour is mandatory for both males and females. ${ }^{135}$ The conception of tzeniut in the Hebrew Bible highlights that modesty is humility and pertains to modest dress. Traditionally, tzeniut includes several guidelines for modest conducts including the prohibition of negiah (physical contact or touch of men and women), kol Isha (the voice of a woman) and other immodest sexual behaviour called kalut rosh (frivolity). Tanach considers the hair of women as the main attractive object to men, in some cases tzniut has become exclusive to the head covering.

The Christian tradition like Judaism has emphasised modesty and observing modest dress. In the Christian tradition, attention to modesty and modest dress of women were common affairs approved by early Christian scholars. In the New Testament the conception of modesty has been manifested as head covering (katakephale) and veil. Also, the chapel veil or mantle and the habit of the nuns are the most familiar religious symbols in Christian history. Nonetheless today, except in some religious groups such as most Amish, Mennonite communities, and Pentecostals that still regard to modesty conduct, many churches have failed to teach this subject. Nowadays, most Christians follow the fashions that usually lead to immodesty with only a minority of them try to dress modestly. ${ }^{136}$

Islamic teachings in the Qur'an and the Sunnah have demonstrated and underscored the conception and

\footnotetext{
${ }^{135}$ Ahituv, "Modesty and Sexuality in Halakhic Literature".

${ }^{136}$ Crank, "Clothing \& Modesty.".
} 
significance of modesty. The Qur'an has demonstrated the importance of modesty as hayā' (modesty) and 'iffah (chastity) with recommendation in using jilbāb and khimār for women as a part of their modest conducts. The modest dress often called hijāb is used in Muslim countries in the different form of jilbāb, khimār, chadur, parda, burqa, abayah, tudung and niqāb depending to their traditions. ${ }^{137}$ Overall, in all these religions' teachings conception of modesty as a common virtue is significant particularly that they recommend wearing modest dress for women in this regard as one of its manifestation.

\section{References}

Ahituv, Yosef. "Modesty and Sexuality in Halakhic Literature, Jewish Women: A Comprehensive Historical Encyclopedia." Jewish Women's Archive. Accessed October 15 2013, http://jwa.org/encyclopedia/article/modesty-andsexuality-in-halakhic-literature. 2009.

Ahmed, Leila. Women and Gender in Islam: Historical Roots of a Modern Debate. Yale University Press, 1992. Al-`Asqalāni, Ibn Hajar. Fath al-Bārì Sharh Sahịh alBukhārī. Riyadh: Dār al-Salam, 2000.

Al-Ali, Nadje. "Veil: Modesty, Privacy and Resistance." Journal of the Royal Anthropological Institute 6(3) (2000): 543-543.

Allhoff, Fritz. "What is Modesty?" International Journal of Applied Philosophy 23(2) (2009): 165-187.

Ameli, Saied Reza. Hijab, Meaning, Identity, Otherization and Politics: British Muslim Women, vol. 4. Islamic Human Rights Commission, 2006.

Andrews, Caryn Scheinberg. "Defining and Exploring Modesty in Jewish American Women." Journal of Religion and Health 50(4) (2011): 818-834.

${ }^{137}$ Anwar, Ghazala, Veiling in Encyclopedia of Islam and the Muslim World (New York: Macmillan, 2004), vol. 2, 721-722. 
Anwar, Ghazala. Veiling in Encyclopedia of Islam and the Muslim World, vol. 2. New York: Macmillan, 2004.

Berlin, Adele et.al. The Jewish Study Bible: Jewish Publication Society Tanakh Translation. Oxford: Oxford University Press, 2004.

Brown, A. Philip. "A Survey of the History of the Interpretation of 1 Corinthians 11:2-16 II." Aldersgate Forum. accessed July 22, 2015, http://www.disciplingnewconverts.org/web_documents/ OtherArticles/2011-10-25, 2011.

Bullock, Katherine. Rethinking Muslim Women and the Veil: Challenging Historical \& Modern Stereotypes. Virginia: IIIT, 2002.

C. Sheehy, Mary, The Dominican Habit. accessed June 21 , 2014 , www.dominicanidaho.org/formation/.../dominican.habit .history.pdf

Castelli, Elizabeth A. \& Rodman, Rosamond C. Women, Gender, Religion a Reader. New York: Palgrave, 2001.

Chesterton, Gilbert Keith. What's Wrong with the World? Cassell, 1912.

Cialdini, Robert B. et.al. "When Social Role Salience Leads to Social Role Rejection: Modest SelfPresentation Among Women and Men in Two Cultures." Personality and Social Psychology Bulletin 24(5) (1998): 473-481.

Coffman, James Burton. Coffman Commentreis on the Old and New Testament. accessed July 20, 2015, http://www.studylight.org/commentaries/bcc/

Crank, David. "Clothing \& Modesty." Magazine Unless the Lord 3(2) (2002).

Daly, M. Catherine. "The Paarda Expression of Hejaab among Afghan Women in a non-Muslim Community," Religion, Dress and Body, ed. Arthur, L.B., 147-161. New York: Berg, 1999. 
De Courtais, Georgine. Women's Headdress and Hairstyles in England from AD 600 to the Present Day. London: BT Batsford Limited, 1986.

Driver, Godfrey Rolles et.al., eds. The Assyrian Laws. Amsterdam: Scientia Verlag, 1975.

Eagly, Alice H. and Acksen, Barbara A., "The Effect of Expecting to be Evaluated on Change Toward Favorable and Unfavorable Information About Oneself." Sociometry (1971): 411-422.

Eichner, Maura. "A Nun Changes Her Habit." Catholic Digest. accessed July 22, 2015, http://www.sturdyroots.org/PDFs/CF/CF_EichnerHabit pdf.pdf

Eidelberg, Paul. Judaic Man: Toward a Reconstruction of Western Civilization. The Caslon Company, New Jersey, 1996.

El Guindi, Fadwa. Veil: Modesty, Privacy and Resistance. Oxford: Berg, 1999.

Facione, Noreen C. "Breast Cancer Screening in Relation to Access to Health Services." Oncology Nursing Forum 26(4) (1999): 689-696.

Falk, E. Sefer 'Oz Ve-hadar Levushah: Modesty, an Adornment for Life: Halachos and Attitudes Concerning Tznius of Dress \& Conduct. New York: Feldheim Publishers, 1998.

Flores-Ortiz, Yvette G. "The Role of Cultural and Gender Values in Alcohol Use Patterns Among Chicana/Latina High School and University Students: Implications for AIDS Prevention." International Journal of the Addictions 29(9) (1994): 1149-1171.

Fuchs, Ilan. "Hair Covering for Single Women: A New Reading of Mizrahi Halakhic Rulings." Nashim: A Journal of Jewish Women's Studies \& Gender Issues 23 (2012): 35-59. 
Gregg, Aiden P. et.al. "Everyday Conceptions of Modesty: A Prototype Analysis." Personality and Social Psychology Bulletin (2008).

HaEzer, Even et.al. Rav Yitzchak Yaacov. Oak Park: Targum Pr, 1985.

Hallpike, Christopher R. "Hair." The Encyclopedia of Religion 6. New York: MacMillan, 1987.

Heatherington, Laurie et.al. "Toward an Understanding of Social Consequences of "Feminine Immodesty" About Personal Achievements." Sex Roles 20(7-8) (1989): 371-380.

Henkin, Yehuda-Herzl. "Contemporary Tseni'ut." Tradition: A Journal of Orthodox Jewish Thought 37(3) (2003): 1-48.

Hillel, ben David, "Comments submitted to: Rabbi Dr. Greg Killian Greg Killian" accessed Oct 8, 2014, http://www.betemunah.org/.

Hoodfar, Homa. "The Veil in Their Minds and on Our Heads: Veiling Practices and Muslim Women." The Politics of Culture in the Shadow of Capital (1997): 248-79.

Hunter, Preston. "Major Religions of the World Ranked by Number of Adherents," http://www. adherents. com/Religions_By_Adherents.html>

Hurley, James B. Man and Woman in Biblical Perspective. Oregon: Wipf and Stock Publishers, 2002.

Hurley, James B. "Did Paul Require Veils or the Silence of Women? A Consideration of 1 Cor. 11: 2-16 and 1 Cor. 14: 33b-36," Westminster Theological Journal 35 (2) (1973): 190-220.

Ibn Anas, Mālik. Al-Muwațta'. Beirut: Dār al-Fikr, 1398 /1978.

Ibn Ḥazm, Abū Muḥammad 'Alī ibn Aḥmad ibn Sa 'īd. AlMuhallāa, tahqiq; Shākir, Aḥmad Muhammad. Lebanon: Dār al-Kutub al-'Ilmiyyah, Beirut, 2012. 
Ibn Mājah al-Qazwīni, Muhammad bin Yazīd. Sunan Ibn Mājah. Beirut: Dār al-Fikr, 1415/1995.

Ibn Manẓūr, Jamāl al-Dīn Muhammad. Lisān al-`Arab, 18 vols. Iran, Qom: Nashr Adab Hawzih, 1405 AH.

Ibrahim, B. Syed. Women in Islam: Hijab Aalim. Louisville: Islamic Research Foundation (IRF), 1999.

Al-Ișfahāní, Abū al-Faraj. Kitāb al-Aghānī, ed. Iḥsān 'Abbās et. al. Cairo, Beirut: Dār Șadr, 2003.

J. B. Phillips. The New Testament in Modern English. New York: Harper Collins, 1958.

J. Coert Rylaarsdam, Encyclopaedia Britannica. accessed Oct 8 , 2014 , http://global.britannica.com/EBchecked/topic/1785796/ Tanakh

Jewish Encyclopedia. accessed Oct 8, 2015, http://www.jewishencyclopedia.com/articles/10729Talmud,1906)

Jones, Edward Ellsworth and Camille B. Wortman. Ingratiation: An Attributional Approach. New York: General Learning Press, 1973.

Keener, C.S. "Man and Woman." Dictionary of Paul and his Letters, eds. Martin, R.P. et.al., 583-592. Leicester: IVP, 1993.

Khan, Sumbul Ansar. "Notion of Veil in Islam: A Sign of Placate or Disconcert among the Women of Karachi, Pakistan," Asian Journal of Social Sciences \& Humanities 3 (2014): 2.

Kraybill, Donald B. Concise Encyclopedia of Amish, Brean, Hutterites and Mennonites. Baltimore, Maryland: Johns Hopkins University Press, 2010.

Kuhns, Elizabeth. The Habit: A History of the Clothing of Catholic Nuns. Bournemouth: Image, 2007.

Lane, Edward William and Lane-Poole, Stanley. An Arabic-English Lexicon: Derived from the Best and the Most Copious Eastern Sources, vol. 2. London: Williams and Norgate, 1865. 
Leary, Mark R. The Curse of the Self: Self-Awareness, Egotism, and the Quality of Human Life. Oxford: Oxford University Press, 2004.

Lorasdağ1, Berrin Koyuncu. "The Headscarf and 'Resistance Identity-Building': A Case Study on Headscarf-Wearing in Amsterdam." Women's Studies International Forum 32(6) (2009): 453-462.

Marshall, Gül Aldikaçti. "Ideology, Progress, and Dialogue: A Comparison of Feminist and Islamist Women's Approaches to the Issues of Head Covering and Work in Turkey." Gender \& Society 19(1) (2005): 104-120.

Martin, Troy W. "Paul's Argument from Nature for the Veil in 1 Corinthians 11: 13-15: A Testicle Instead of a Head Covering." Journal of Biblical Literature123(1) (2004): 75-84.

Mernissi, Fatima. Women and Islam: An Historical and Theological Inquiry. Missouri: South Asia Books, 1991. Mohanty, Chandra Talpade. "Under Western Eyes: Feminist Scholarship and Colonial Discourses." Feminist Review 30 (1988): 61-88.

Motahhari, Murtadha. The Islamic Modest Dress, translation by Bakhtiar, Laleh, 3rd edn. Chicago. IL: Kazi Publications, 1992.

Murphy-O'Connor, Jerome. "Sex and Logic in 1 Corinthians 11: 2-16." Catholic Biblical Quarterly Washington DC 42(4) (1980): 482-500.

Nee, Watchman. An In-Depth Study of 1 Corinthians 11:1-16. Richmond, Torch Publications. accessed July 3 , 2015 , http://truthinheart.com/EarlyOberlinCD/CD/Doctrine/B eVeiled.htm

Nyamaah, Emmanuel et.al. "Christianity and Culture in Ghana: A Study of the Church of Pentecost's Decree on Head Covering and 1 Corinthians 11:2-16." 
Proceedings 1st Annual International Interdisciplinary Conference, AIIC, Azores, Portugal, 24-26 April 2013. Orr, James, ed. The International Standard Bible Encyclopaedia, vol. 4. Howard-Severance Company, 1915. Entry for 'mantle'. accessed Oct 3, 2015, http://www.studylight.org/encyclopedias/isb/view.cgi?n $=5735 \&$ search $=$ span

Oxford English Dictionary. Oxford University Press, (1989). accessed July 6, 2015, http://www.oxforddictionaries.com/definition/english/h abit

P. Gregg, et.al. "The Importance of Being Modest." The Self: Frontiers in Social Psychology, eds. C. Sedikides \& S. Spencer, 163-184. New York: Psychology Press, 2007.

Rāghib Iṣfahānī, Abū al-Qāsim Ḥusayn ibn Muḥammad. Al-Mufradāt fī Gharīb al-Qur'ān. Damascus: Dār alQalām, 1992.

Raisler, Jeanne. "Against the Odds: Breastfeeding Experiences of Low Income Mothers." Journal of Midwifery \& Women's Health 45(3) (2000): 253-263.

Read, Jen'nan Ghazal and Bartkowski, John P. "To Veil or Not to Veil? A Case Study of Identity Negotiation Among Muslim Women in Austin, Texas." Gender \& Society 14(3) (2000): 395-417.

Reagan, Leslie J.. "Engendering the Dread Disease: Women, Men and Cancer." American Journal of Public Health 87(11) (1997): 1779-1787.

Reischer, Erica and Koo, Kathryn S.. "The Body Beautiful: Symbolism and Agency in the Social World." Annual Review of Anthropology (2004): 297-317.

Ruby, Tabassum F. "Listening to the Voices of Hijab." Women's Studies International Forum 29(1) (2006): 5466.

Rudman, Laurie A. "Self-Promotion as a Risk Factor for Women: The Costs and Benefits of 
Counterstereotypical Impression Management." Journal of Personality and Social Psychology 74 (3) (1998): 629.

Schachter, Elli P. "Identity Configurations: A New Perspective on Identity Formation in Contemporary Society." Journal of personality 72(1) (2004): 167-200. Schmiedicke, Regina. "Modesty and Beauty - the Lost Connection." Concourse, an Independent Journal of Opinion 4(5) (1999).

Schwartz, Howard. Tree of Souls: The Mythology of Judaism. Oxford: Oxford University Press, 2004.

Seigelshifer, Valeria and Hartman, Tova. "From Tichels to Hair Bands: Modern Orthodox Women and the Practice of Head Covering." Women's Studies International Forum 34(5) (2011): 349-359.

Sepinwall, Sharyn Weinstein. "Women of Valour: Literacy as the Creation of Personal Meaning in the Lives of a Select Group of Hassidic Women in Quebec." Thesis, Faculty of Education, McGilI University, Canada, 2002.

Shalit, Wendy. A Return to Modesty: Discovering The Lost Virtue. New York: Simon and Schuster, 2000.

Shank, Tom. An In-Depth Study of 1 Corinthians 11:1-16.

North America: Torch Publications, 1992.

Siddiqui, Mona. "Veil". Encyclopedia of the Quran, ed. J. McAuliffe. 412-416 Leiden, Netherlands: Brill Academic Publishers, Leaman, O, 2004.

Smith, William et.al. Smith's Bible Dictionary, Pyramid Books, 1967. entry for 'mantle.' accessed July 6/2015, http://www.classic.studylight.org/dic/sbd/view.cgi?num ber $=\mathrm{T} 2830>$.

Ssenyonjo, Manisuli. "The Islamic Veil and Freedom of Religion, the Rights to Education and Work: A Survey of Recent International and National Cases." Chinese Journal of International Law 6(3) (2007): 653-710. 
Sullivan, Rebecca. "Breaking Habits: Gender, Class and the Sacred in the Dress of Women Religious." Consuming Fashion: Adorning the Transnational Body (1998): 109-128.

T. Lewis, John. The Posture in Prayer and Covered and Uncovered Heads in Worship. Birmingham: AL, 1947.

T. Massey, Preston. "The Meaning of $\kappa \alpha \tau \alpha \kappa \alpha \lambda v ́ \pi \tau \omega$ and $\kappa \alpha \tau \grave{\alpha} \kappa \varepsilon \varphi \alpha \lambda \tilde{\eta} \varsigma$ है $\chi \omega \nu$ in 1 Corinthians 11.2-16." New Testament Studies 53 (4) (2007): 522.

Tabatabai, Fakhrossadat. "The Veil: Symbol and State Identity, Iran and France." International Relations Master's Program, John W. McCormack Graduate School of Policy and Global Studies, University of Massachusetts, Boston, 2011.

Ternikar, Farha. "Hijab and the Abrahamic Traditions: A Comparative Analysis of the Muslim Veil." Sociology Compass 3(5) (2009): 754-763.

The American Heritage ${ }^{\circledR}$ New Dictionary of Cultural Literacy, third edition. accessed June, 6, 2015, http://dictionary.reference.com/browse/vatican ii)

Vine, William Edwy. An Expository Dictionary of New Testament Words: With Their Precise Meanings for English Readers. Nashville: Thomas Nelson Inc, 1985. Walter, Elizabeth. ed. Cambridge Advanced Learner's Dictionary Hardback with CD-ROM for Windows and Mac Klett Edition. Stuttgart: Ernst Klett Sprachen, 2008 Weiss, Susan. "Under Cover: Demystification of Women's Head Covering in Jewish Law." Nashim: A Journal of Jewish Women's Studies \& Gender Issues 17(1) (2009): 89-115.

Willig, Mordechai. "Modesty: A Timeless Principle." The Torah Web Foundation, accessed Oct 8, 2015, http://www.torahweb.org/torah/2010/parsha/rwil_bamid bar.html

Wosinska, Wilhelmina et.al. "Self-Presentational Responses to Success in the Organization: The Costs 
Zohreh, Wan Zailan \& Mohammad Ali, , "The Conception of Modesty and Modest Dress," Afkār Vol. 18 Issue 2 (2016): 229-270

and Benefits of Modesty." Basic and Applied Social Psychology 18 (2) (1996): 229-242.

Zalcberg, Sima. "Grace is Deceitful and Beauty is Vain: How Hassidic Women Cope with the Requirement of Shaving One's Head and Wearing a Black Kerchief." Gender Issues 24 (3) (2007): 13-34. 